\title{
Implementation Of Decisions And Obstacles Administrative Court - Implementation Obstacles
}

\begin{abstract}
Hasto Sasmito ${ }^{1}$
Abstract. Indonesia is a country of law. The rule of law means in our country is the law that has significance especially in all aspects of community life. Everything implementation carried out by the state through its government should be appropriate and according to the channels that have been determined in advance by law. Judicial Administration is a special court, which was given the authority to resolve disputes that arise in the field of administration and personnel or disputes that occur between administration officials with a person or body of civil law as a result of the issuance or issuance of a decision. Act no. 5 of 1986 on State Administration aims to provide a container or a space for people and civil legal entity to file a lawsuit to the Administrative Court (PTUN) for the issuance of an administrative decision (KTUN), then his rights to feel disturbed or harmed but in practice administrative court ruling will not necessarily be implemented because of constraints exist that impede the implementation of the decision of the Administrative Court. Thus the presence of the administrative court as an institution that is expected to be a means of enforcement and legal protection in the field of administration can not be carried out effectively and still needed revision of the law.

Keywords: State Administrative Court (PTUN).
\end{abstract}

\section{Introduction}

A good law according to Lawrence Friedman ${ }^{2}$ should always contain elements of the legal system that consists of 3 parts: Structure of law (legal stucture); Legal substances (legal substance); and Legal culture (legal culture).

Therefore, everything that will be implemented in a national legal system of a country must be adapted to the conditions and the interests or objectives of the country concerned. In the Indonesian context, it can be implemented by adjusting the values or principles terdap in Pancasila (as filosofische grondslag) Act of 1945 (as staats fundamental norm). ${ }^{3}$

The existence of the Act of 1945 and the laws that are below it, certainly must be addressed to achieve the goals or ideals of Pancasila. This is because the position or the presence of Pancasila as the ideals of law (rechtsidee) which is a guiding star. With this position requires the purpose of establishing the 1945 Constitution and all positive law here at home is to achieve the ideas or values and ideals of Pancasila. ${ }^{4}$

Furthermore, the law states a view born of Juliuas Stahl. As with Kant, Julius Stahl also use the term rechtstaat. Juliuas Stahl said the four elements that must be contained in rechtstaat in the classical sense. The four elements in question are as follows:

- The protection of human rights;

- The division or separation of power of the state to guarantee these rights (the state

\footnotetext{
${ }^{1}$ Student of Masters (S2) of Law Faculty of Law Unissula Semarang email: h445tosasmito@gmail.com

${ }^{2}$ Lawrence Friedman American Law 1984

${ }^{3}$ Yopi Gunawan dan Kristian Perkembangan Konsep Negara Hukum dan Negara Hukum Pancasila Refika Aditama 2015.

${ }^{4}$ Ibid.
} 
based on the theory triad politics);

- The rule of law (wetmatigheid van bestuur) and

- Their administrative tribunals or administrative courts in disputes (there are administrative tribunals or administrative courts in charge of handling cases of unlawful acts committed by the government). ${ }^{5}$

With the recognition of the concept of state law as stated in the constitution of the Republic of Indonesia, namely in Article 1 paragraph 3 of the Constitution of 1945, which expressly stated that the Republic of Indonesia is a country of law, of course have the consequence of juridical should be accounted for in the practice of social, civic and state. By claiming to be a state of law, then Indonesia must satisfy and fulfill all the requirements and principles - the principles contained in the law state in the practice of nation, state and society. ${ }^{6}$

As a state law, it is proper principles of a state of law must be respected and upheld. One of them was admitted expressly in the Act No. 48 of 2009 Article 10 paragraph (1) regarding the power of Justice who determines "that the Court prohibited from refusing to examine, decide upon a case filed with the proposition of law does not exist or is less clear, but obliged to examine and hear ". 7

In carrying out the duties administrative that there are possibilities of government to do things that feel harm or violate the rights of citizens so that may also arise a conflict, discord or dispute between the Agency or Official State Administration with the citizens of society which could harm or hinder the course of national development. To anticipate the dispute then the Courts that have absolute competence specifically which agency Judicial Administration of the State or the State Administrative Court that is able to dispense justice, truth, order and legal certainty so as to provide shelter to the people, especially in the relationship between the Agency or Official Administration countries with the community.

However, even though the existing State Administrative Court, according to the authors there are problems related to the "implementation of the administrative court ruling".

\section{Result And Discussion}

\subsection{Basic Concepts Of The Birth Of The State Administrative Court}

Indonesia is a country of law. The rule of law means in our country is the law that has significance especially in all aspects of community life. Everything implementation carried out by the state through its government should be appropriate and according to the channels that have been determined in advance by law.

One function of law is to regulate (regelen) act of legal subjects. It has been mentioned that the legal subjects consisted of humans (Natuurlijk persoon), legal entities (rechtspersoon), and function (ambt), each of which cling to the rights, obligations and authority. In order to support the rights and obligations - on the basis of proficiency (bekwaam) or authority (bevoegdheid) - each the subject of law it will perform legal acts (rechtshandelingen), which acts result in legal consequences, and hold legal relationship (rechtsbetrekking), the interaction between legal subjects which have legal relevance or

\footnotetext{
${ }^{5}$ Philipus M.Hajohn 1987 Perlindungan Hukum Bagi Rakyat di Indonesia Bina IImu ,Surabaya

${ }^{6}$ Yopi Gunawan dan Kristian,Perkembangan Konsep Negara Hukum dan Negara Hukum Pancasila,Refika Aditama 2015 p. 80

${ }^{7}$ Ibid.
} 
have legal consequences (rechtsgevolgen). Acts and legal relationships governed by law that each legal subject that can obtain his rights legally and carry out the obligations of legally anyway. In this case the legal act in question is a legal act of an administrative nature (bestuursrechtelijk rechtshandeling), which is a legal act a statement of intention to appear on the organ administration in special circumstances, intended to give rise to legal consequences in Administrative Law, and the legal relationship of an administrative nature (bestuurrechtiiljk rechtsbetrekking), namely the relationship inter-governmental organs with other government organs, included the law agencies, and with one or several citizens, which is governed by the norm of law (administration). ${ }^{8}$

In practice though legal actions and legal relations have been governed by the rule of law, but not always legal relationships between legal subjects walked harmonious, balanced and fair, or implemented in accordance the applicable legal norms. This is possible because at certain moments does not perform its obligations legally so that there is a subject hukumlain disturbed or violated their rights, or there are saan particular legal relationship one legal subject was intentionally or through negligence violates the rights of legal subjects other. Because of this legal protection is required for as guarantees provided by the law for legal subjects who violated their rights by other legal subjects to gain back their rights legally.

It was generally known that in order to carry out the duties, functions and authority, the government will undertake various action (feittelijkhandelingen) as well as legal action (rechtshandelingen). Concrete actions are actions which had no relevance to the law therefore does not give rise to legal consequences, while the legal action is an act that by its nature can cause due to certain laws., The consequences of which have relevance or legal consequences that may include the creation of new legal relationship, amendment or termination of the existing law, or it can also be the emergence of some changes to the rights, obligations, and powers there, cause changes in a person's legal position or the determination of the rights, obligations, and certain legal status. ${ }^{9}$

Judicial Administration is a special court, which was given the authority to resolve disputes that arise in the field of administration and personnel or disputes that occur between administration officials with a person or body of civil law as a result of the issuance or issuance of a decision. This is in accordance with the General Explanation of point (5) of Act no. 5 of 1986 which states that ${ }^{10}$ : "The law is used in the event that the Administrative Court have similarities with the procedural law that is used in general courts for civil matters, with some differences as follows:

- In the administrative court judges more active role in the proceedings in order to obtain the material truth and for that this law leads to the teachings of free proof;

- A State Administrative Lawsuit Basically Is Not To Delay The Implementation Of The Disputed KTUN.

\subsection{Judicial Administration Procedural Law Applied By Referring To The Principles Underlying The Legal Process Of Dispute Resolution In The Field Of The General Principles Of The Criminal Procedure Judicial Administration.}

In the state administration to these principles in the context of law is regarded as the

\footnotetext{
${ }^{8}$ Ridwan HR Tiga Dimensi Hukum Administrasi Dan Peradilan Administrasi ,FH UII Press p.119

${ }^{9}$ Ridwan HR Op cit. p.121

${ }^{10}$ Act no. 5 of 1986 concerning State Administrative Court
} 
"heart" of law rules or ratio legis of legislation. The principle of law is a basic thought that the general nature or the background of the rules concrete contained in and behind every legal system terjelama in legislation and the judge's decision is a positive law and can be found by searching for common properties in the regulation of concrete the. ${ }^{11}$

The principles underlying the implementation of the Justice Administration or the State Administration are as follows:

- Presumption Principle Rechtmatig. This principle with regard to the legal acts of government (bestuursreht-handeling), especially embodied in KTUN publication. In the concept of a state of law, any government action should be based on applicable legislation or under the authority diberikanb by laws and regulations, including when the government makes a nd publish KTUN. Normatively, every creation and publishing KTUN besides discretion must also satisfy the formal requirements and material requirements, which have been met, then KTUN published it was considered lawful (vermoden van het rechtmatigheid). Because KTUN which have been issued by the government was legally valid, then in principle uutuk KTUN concerned not revoked, until proven otherwise by or through pengadilana. Thus, if on KTUN that no suit or still in the process of examination in court, KTUN was considered lawful (rechsgeldig) even though it contains legally binding (rechtsgebreken).

- The lawsuit does not delay the implementation of the principle of KTUN. The assumption that every KTUN issued by the government was always considered to be lawful impact that the lawsuit filed with the administrative court judge did not affect the implementation of the KTUN. In other words, basically a decision will still be implemented even if there is a lawsuit against KTUN concerned. Even so can only be suspended or postponed when there is a lawsuit against the KTUN. In Article 67 paragraph (2) of Act no. 5 of 1986 stated: "The claimant may request that the implementation was postponed for examination KTUN State Administration dispute ongoing, until there is a court decision that had permanent legal power". Reason KTUN postponement mentioned in Article 67 paragraph (4); Request Delay referred to in Article 67 paragraph (2):

- May be granted only where there is a very urgent situation which resulted in the interest of the claimant be harmed if KTUN who sued it remain to be implemented;

- Not be granted if the public interest in the development requires the implementation of the decision.

- Judge active principle. In contrast to the role of judges in civil law and criminal that is passive, in the sense that judges are only waiting for the arguments put forward by the parties, the role of the judge in the procedural law Administrative Court is active, not just wait and tied to the arguments put forward by the parties dispute.

- The award shall be Erga omnes principle. This principle implies that the administrative court ruling was binding on the parties to the dispute. This is because the decision of the administrative court judge within the scope of public law or bind the public and bind to the dispute that contain equations, which may arise in the future.

- The principle of Justice is done with a simple, fast, and inexpensive. According Sudikno Merto Kusumo, is a simple event is clear, easy to understand and straightforward. A quick word refers to the course of justice. To much formality is an obstacle course of

${ }^{11}$ Sudikno Mertokusumo Mengenal Hukum Liberty, Yogyakarta,p.33 
justice. Specified low cost, so terpikul by the people. Most cases high costs led to the interested parties are reluctant to litigate the rights to the Court. ${ }^{12}$

- Examination Principle Aspects Rechmatig not Doelmatig. It has been mentioned that in the event the law of administrative court judges adopted active principle. Nevertheless, the role of an active judge is not without limits. The judge is only authorized to investigate and resolve disputes from the legal aspect. This means that even disagree on the wisdom of the issuance of the decision, he should not discuss it (geen ordeel over de doelmatigheid). Judges may only examine whether or not a decision contrary to the terms legitimate or not, not whether or not the decision was issued.

\subsection{Decision and the implementation of decisions}

- Decision

Decision of judge (vonnis) is a statement by the judge, as a state official authorized to it, uttered in the hearing and aims untun end or settle a problem or dispute between the parties. ${ }^{13} \mathrm{Administrative} \mathrm{court} \mathrm{ruling} \mathrm{in} \mathrm{accordance} \mathrm{with} \mathrm{Article} 97$ paragraph (7) of Act no. 5 of 1986 is as follows: Lawsuit rejected; The lawsuit was granted; The suit is not accepted; and Lawsuit fall.

In the case of lawsuit granted, pursuant to Article 97 paragraph (8) then in the court's ruling could set obligations to be performed by the agency or official who issued the state administration KTUN. Furthermore, Article 97 paragraph (9) states that the obligation referred to in Article 97 paragraph (8) is as follows:

- Revocation KTUN concerned;

- Revocation KTUN concerned and issue new KTUN; or

- Publishing KTUN in the case of a lawsuit based on Article 3 (10) The obligation under paragraph (9) can be accompanied by compensation.

- Implementation of the decision.

According M.Yahya Harahap, as quoted by Victor Yaved Neno, a decision that can be executed are: The verdict has obtained permanent legal force, because the decision has legal force tertap have contained a form of legal relationship between the fixed and definite litigants.

\subsection{Verdict implementation constraints}

Although the provisions of Article 116 of Act no. 5 of 1986 has been so clear about the execution of court decisions that have obtained permanent legal force, but in practice still allows the constraints, both theoretical and practical, for the following matters:

- The principle that of the object - the public body can not be put sequestration;

- The principle of "rechtmatigheid van bestuur".

- One consequence of this principle is the principle of authority. Officials justified the boss does not publish KTUN that certain officials should be authorized under. Thus suppose officials below it superiors ordered officials to issue a KTUN and was not done, officials KTUN boss can not publish them;

- The principle that freedom can not be deprived of government officials. Likelihood of this principle may not be an official eg under house arrest for not carrying out the court

\footnotetext{
${ }^{12}$ Sudikno Mertokusumo Hukum Acara Perdata Indonesia Liberty p.23

${ }^{13}$ Ibid.
} 
verdict TUN;

- The principle that the state (in this case) the government should always be considered to be "solvable" (able to pay). ${ }^{14}$

\section{Closing}

\subsection{Conclusion}

From the description above, we can conclude the following things: That Act no. 5 of 1986 concerning the State Administrative Court aims to provide a container or a space for people and civil legal entity to file a lawsuit to the Administrative Court for the issuance KTUN, their rights to feel disturbed or harmed but in actual administrative court ruling will not necessarily be implemented because of constraints -kendala that there is hampering the implementation of the administrative court ruling.

\subsection{Suggestion}

The presence of the Administrative Court as an institution that is expected to be a means of enforcement and legal protection in the field of administration can not be carried out effectively would require a revision of the law - the law or follow up with the implementation of the regulation in which makes provision:

- The scope of the authority of the bailiff and any objects that may be seized;

- Objective and subjective error criteria for officials;

- Determination of the competent authorities or institutions impose sanctions, in terms of state administrative official does not comply with the judge's ruling that contain sanctions;

- Criteria for determining the time limit announcement in the mass media;

- Determination of internal penalties for officials who violate these procedures and mechanisms.

\section{Bibliography}

[1] Act no. 1986 on the State Administrative Court

[2] Constitution of the Republic of Indonesia Year 1945 and Amendments;

[3] Philipus M.Hajohn 2015 Pengantar Hukum Administrasi Indonesia Gadjah Mada University Press

[4] Philipus M.Hajohn,1987 Perlindungan Hukum Bagi Rakyat Indonesia Bina Ilmu

[5] Ridwan HR 2009 Tiga Dimensi Hukum Adminstrasi dan Peradilan Administrasi FH UII Press.

[6] Sudikno Mertokusumo 2002 Hukum Acara Perdata Indonesia Liberty

[7] Victor Yaved Neno 2006 Implikasi Pembatalan Kompetensi Absolut Peradilan Tata Usaha Negara Citra Aditya Bhakti

[8] Yopi Gunawan dan Kristian 2015 Perkembangan Konsep Negara Hukum dan Negara Hukum Pancasila Refika Aditama

\footnotetext{
${ }^{14}$ Philip M.Hajohn Introduction to the Law of Administration of Indonesia Gadjah Mada University Press 1993 hal.369
} 